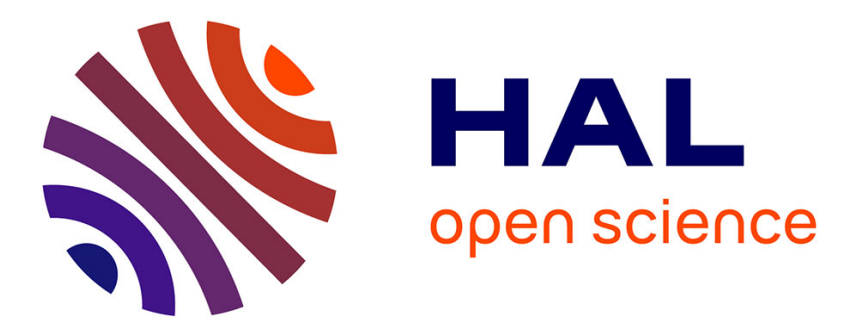

\title{
Support Policies and Collective Efficiency in a Furniture Cluster
}

\author{
Elizangela Lima, Walter C. Satyro, Jose B. Sacomano, Esdras Barboza, \\ Renato Telles
}

\section{- To cite this version:}

Elizangela Lima, Walter C. Satyro, Jose B. Sacomano, Esdras Barboza, Renato Telles. Support Policies and Collective Efficiency in a Furniture Cluster. IFIP International Conference on Advances in Production Management Systems (APMS), Sep 2016, Iguassu Falls, Brazil. pp.272-279, 10.1007/9783-319-51133-7_33. hal-01615714

\author{
HAL Id: hal-01615714 \\ https://hal.inria.fr/hal-01615714
}

Submitted on 12 Oct 2017

HAL is a multi-disciplinary open access archive for the deposit and dissemination of scientific research documents, whether they are published or not. The documents may come from teaching and research institutions in France or abroad, or from public or private research centers.
L'archive ouverte pluridisciplinaire HAL, est destinée au dépôt et à la diffusion de documents scientifiques de niveau recherche, publiés ou non, émanant des établissements d'enseignement et de recherche français ou étrangers, des laboratoires publics ou privés.

\section{(c)(1)}

Distributed under a Creative Commons Attribution| 4.0 International License 


\title{
Support Policies and Collective Efficiency in a Furniture Cluster
}

\author{
Elizangela Maria Menegassi de Lima ${ }^{1}$, Walter C. Satyro ${ }^{2}$, José B. Sacomano ${ }^{2}$, Esdras \\ Jorge Santos Barboza ${ }^{2}$ and Renato Telles ${ }^{2}$ \\ 1 Paranaense University, Umuarama, Brazil \\ menegassi@unipar.br \\ 2 Paulista University, São Paulo, Brazil
}

\begin{abstract}
The aim of this research is to analyze the support policies and the collective efficiency in a furniture cluster in the South region of Brazil, subject of scarce studies despite its importance. Using quantitative methodology we made a survey with 20 companies of this furniture cluster. The results indicated that support policies and collective efficiency were statistically correlated. The contribution of this paper to the literature is to reinforce that the findings that support policies are a way to improve collective efficiency, and so provide competitiveness to all the companies that belong to the cluster. This research was made on a temporal transversal cut, a characteristic of studies in networks, so the result does not allow generalizations.
\end{abstract}

Keywords: Cluster· Human Capital · Technology · Innovation ·Qualitative

\section{Introduction}

Contemporary companies need to be competitive to manage their businesses in the face of the turbulence imposed by the globalized environment of the economy. In addition, the companies look for to adapt to the new patterns of competition, effects of technology on competitiveness, cultural influences and other environmental factors that affect the day-to-day of the companies [1].

The competitive environment forces the companies around the world to reduce costs to provide innovative products / services in a demand led by consumers and supply chains stimulated by the buyers [2,3]. In order to overcome this situation new organizational arrangement appeared, formed by groups of companies in strategic alliances, called interorganizational networks [4] that can be defined as a group of interdependent companies, involving the use of services and good, production and distribution [5].

Under the standpoint of the interorganizational network, a cluster can be seen as a group of companies that belongs to similar and / or complementary sector, located in a certain geographical region [6,7].

Organizational theory is especially interested in networks, trying to understand the complemental system of interdependence, such as production, coordination, research and engineering, which is different from the analysis of a simple company $[6,7]$.

The analysis of the competitiveness of clusters in relation to collective efficiency, government policy support, human capital, governance, logistics, technology, quality 
and productivity is essential to understand the factors that can provide competitiveness to a cluster in its stage of development [4].

The Brazilian furniture industry is made up of 13,500 companies, corresponding to 10,000 micro, 3,000 small and 500 medium companies approximately, situated mostly in the Central-South region of Brazil [8]. The state of Parana is among the largest producers of furniture in Brazil, and in the city of Umuarama is located the second largest furniture cluster of this state, with a consumption of $3,000 \mathrm{~m} 3$ of wood per month [9].

Using quantitative methodology, the aim of this research is to analyze support policies and collective efficiency that can provide competitiveness to the furniture cluster of the city of Umuarama, subject of scarce studies despite of its importance.

\section{Literature Review}

\subsection{Support Policies}

The competitiveness of the companies can be determined by various factors, such as networks, human resources, customers and government support policies, among others [10]. Support policies are the policies that try to improve the efficiency and competitiveness of the companies [10]. Efficiency is associated to the ability of a policy measure to support growth without generating negative feedback effects [11,12].

Support policies can increase the competitiveness of the clusters and have a potential to support the recovery of development, contributing to the generation of income and employment, and so reducing the regional and social inequalities [13].

\subsection{Industrial Clusters}

The competition of the modern days forces the companies to have so many capacities and abilities to compete that it is no more possible to operate alone; to overcome these requirements, the companies form strategic alliances with other companies, including customers, suppliers, or even competitors to survive [14].

The complexity to compete is so great that it is possible to say that all companies operate in networks, from small to big enterprises, using or not connections with their partners [15]. The interorganizational network and the companies that belong to it share, exchange and also joint development technology, products or services among themselves [14].

A cluster can be defined as a sectoral and geographical concentration of companies that provide efficiency gains, which the companies that compete individually, can seldom achieve [16]. The cluster is formed by suppliers, competitors and complementary companies that in order to provide competitive advantage to these companies, exchange information, knowledge, expertise, and products / services [14].

In the cluster, the companies cooperate among themselves, but at the same time, they compete in the market $[4,5]$. The cluster can also provide geographical development to the area where it operates, and one example can be presented: the BioRegion of Catalonia, Spain that deals with bioscience and medical technology, formed by 481 companies, 80 research centers, 15 hospitals and 12 universities [17]. 


\subsection{Collective Efficiency}

Collective efficiency can be understood as the ability and capacity of a group to organize and execute actions needed to conduct to objectives that the companies, which belongs to this group, could not reach individually [18].

The cluster per se is a way to improve collective efficiency by the interrelationship of the many companies that form the cluster, enabling these companies to obtain positive results, improving competitiveness [19] to ensure the market or to reduce the competition [20]. Cooperation between these companies is important to lead to collective efficiency [21].

In the cluster the collective efficiency is gained by the competitive advantage that comes from joint actions and local external economies [16]. Collective efficiency is derived from the individual action and from the consciously chased joint action [18].

\section{Methodology}

We wanted to analyze a phenomenon (support policy and collective efficiency) in a certain population (furniture cluster), so we used a descriptive approach with a degree of exploratory research [22] and quantitative methodology of analysis [23], where the collected evidences and data can be measured in order to use statistic to investigate the results [24].

In the Furniture Union of the city of Umuarama we got the general information and main contact of the 56 companies that constitute this furniture cluster. By email we kept in touch with them explaining in general terms our research, and two days later, we sent the survey by email. After a week we sent an email to schedule a meeting to collect personally the questionnaires.

In total we gathered 20 answered questionnaires. These questionnaires were divided in two parts; in the first one we asked general questions and in the second one we introduced some assertions based on a Likert scale of five points [25]. We used the IBM SPSS Statistic v. 21 to test the Pearson correlation coefficient between the assertions.

\section{Results}

From these 20 companies, $55 \%$ were established for over 10 years, $30 \%$ from 5 years to 10 years and the left $15 \%$ from 2 to 4 years, as exhibited in Figure 1.

The majority of these companies, $95 \%$, hire people locally and just one uses to hire $60 \%$ of its workforce locally and $40 \%$ from surrounding cities. These companies were critic about the relationship between them and the institutions that could provide support policies: $65 \%$ did not trust in this relationship, 30\% trusted partially and 5\% trusted, as shown in Figure 2.

This rate of distrust was attributed by $80 \%$ to the lack of cooperation between the institutions that could provide support policies and these companies; and the other 20\% believed that this cooperation was partial, as presented in Figure 3.

The majority of these companies, $85 \%$, did not agree that the support policies that these institutions could provide took into account the interests of the majority of the companies, and $15 \%$ agreed partially, as exhibited in Figure 4. 


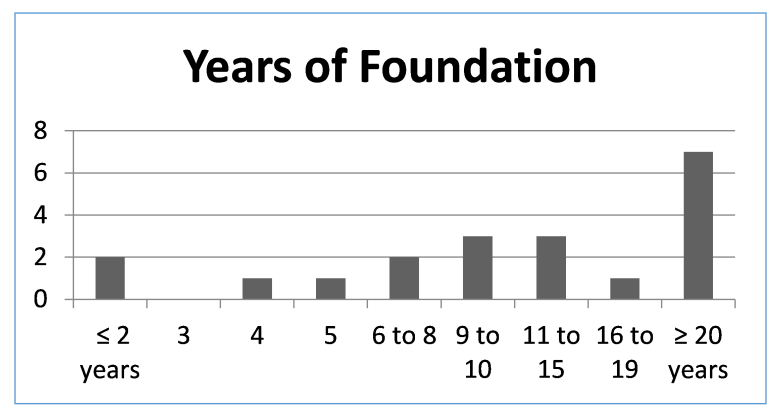

Fig. 1. Years of company foundation in the cluster studied

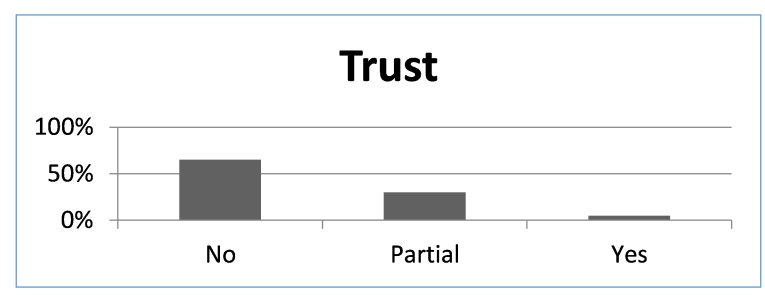

Fig. 2. Trust between these companies and the institutions that could provide support policies

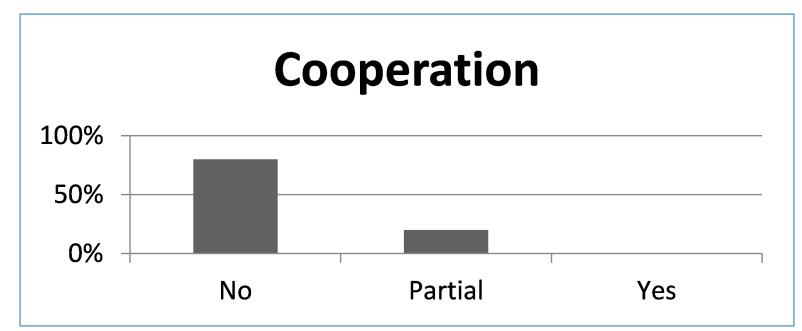

Fig. 3. Cooperation between the institutions that could provide support policies and these companies

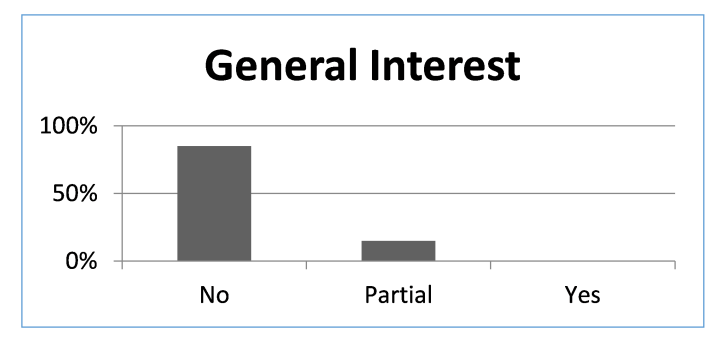

Fig. 4. Respect to the general interest of these companies 
The vast majority, $85 \%$ of these companies, did not agree that these institutions were democratic in their decision taking; and 15\% agreed partially, as displayed in Figure 5.

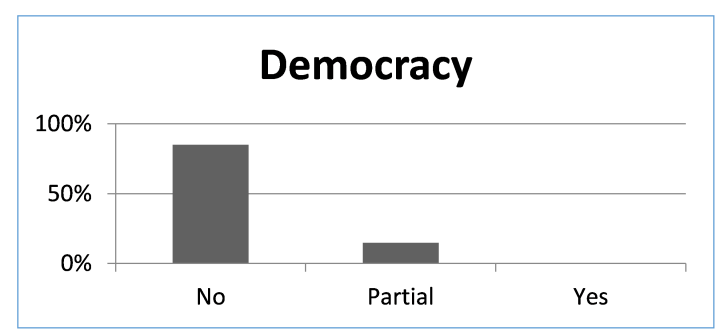

Fig. 5. Democracy in the decision taking by the institutions that could provide support policies

On the other hand, these companies did not seek to approach these institutions to improve this grade of relationship; $80 \%$ did not have any involvement with these institutions and $20 \%$ had a partial involvement, as exhibited in Figure 6.

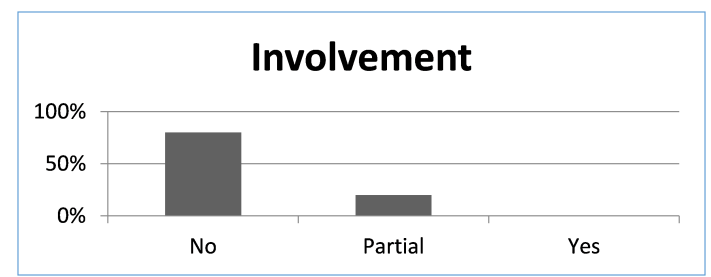

Fig. 6. Grade of involvement between the institutions that could provide support policies and these companies

In the questionnaires there were three assertions about support policies related to: trust, government support policies and competitiveness; and other three about collective efficiency related to: cooperation, general interest and competitiveness, in a Likert scale of five points. Using the data of the questionnaires we made the analysis of the Pearson correlation coefficient (r) between support policies and collective efficiency, using the statistical software IBM SPSS version 21, as shown in Table 1.

The Pearson correlation coefficient ( $r$ ) equal to 0,952 at a level of significance $p$ value for two tailed test of $4.8 \%$ suggested a strong correlation between support policies and collective efficiency. The assertions that got correlation were: (a) Support policies are important to bring competitiveness to our companies, and (b) Collective efficiency can improve competitiveness of our companies.

This result suggested that these companies valorized support policies to bring collective efficiency and so bring positive results, providing competitiveness to this furniture cluster [19], although these companies did not trust in the institutions that were 
Table 1. Pearson correlation coefficient (r)

\begin{tabular}{|c|c|c|c|}
\hline & & Collective Efficiency & Policy \\
\hline \multirow{2}{*}{ Collective Efficiency } & $\begin{array}{l}\text { Pearson } \\
\text { Correlation }\end{array}$ & 1 & $.952 *$ \\
\hline & Sig. (2 extremities) & & 0.048 \\
\hline \multirow[t]{2}{*}{ Support Policy } & $\begin{array}{l}\text { Pearson } \\
\text { Correlation }\end{array}$ & * & 1 \\
\hline & Sig. (2 extremities) & 0.048 & \\
\hline
\end{tabular}

supposed to support them, due to the lack of cooperation of these institutions to the companies.

\section{Conclusion}

This research investigated the support policies and the collective efficiency in the furniture cluster of the city of Umuarama, located in the State of Parana, Brazil. We analyzed 20 companies of this cluster, in a total of 56 that were registered in the Furniture Union of this city.

The prevailing part of these companies was established for over 10 years. These companies were critic about the relationship between themselves and the institutions that could provide support policies. The greater part did not trust in this relationship, and this rate of distrust was attributed by the majority of the interviewed to the lack of cooperation between themselves and these institutions. These companies did not agree that the support policies that these institutions could provide took into account the interests of the majority of the companies, or that these institutions were democratic in their decision taking. On the other hand, these companies did not seek to approach these institutions to improve the grade of relationship, what can keep the situation.

Using statistic we could correlate support policies and collective efficiency, suggesting that these companies valorized support policies [10]] to bring collective efficiency to improve the competitiveness of this furniture cluster $[4,5,14,19]$, although these companies did not trust in the institutions that were supposed to support them, due to the lack of cooperation of these institutions to the companies.

We suggest that the same research could be done in some other cluster to compare the results. As a characteristic of studies in networks, this study was based on a temporal transversal cut, so the results do not allow generalizations.

\section{Acknowledgements}

The authors acknowledge CAPES - Coordenacao de Aperfeicoamento de Pessoal de Nivel Superior of the Ministry of Education, Federal Government, Brazil, for the resources to make this research. 


\section{References}

1. Tilahun, N., Fan, Y.: Transit and Job Accessibility: An Empirical Study of Access to Competitive Clusters and Regional Growth Strategies for Enhancing Transit Accessibility. Transport Policy 33, 17-25 (2014)

2. Sun, Y., Shang, R.A.: The Interplay Between Users' Intraorganizational Social Media Use and Social Capital. Computers in Human Behavior 37, 334-341 (2014)

3. Hahn, M.H., Lee, K.C., Lee, D.S.: Network structure, organizational learning culture, and employee creativity in system integration companies: The mediating effects of exploitation and exploration. Computers in Human Behavior 42, 167-175 (2015)

4. Amato Neto, J.: Gestao de Sistemas Locais de Producao e Inovacao (clusters/APLS): Um Modelo de Referência. São Paulo, Atlas

5. Reis, J.G.M., Neto, M.M., Vendrametto, O., Costa Neto, P.L.O.: Qualidade em Redes de Suprimentos: A Qualidade Aplicada ao Supply Chain Management. São Paulo, Atlas (2015)

6. R., H., H., I.: Competition, Competitive Advantage and Clusters: The Ideas of Michael Porter. Competition, Competitive Advantage and Clusters: The Ideas of Mi-chael Porter (2011)

7. Lima, E.M.M., Pona, J.G.A., Sacomano, J.B., Reis, J.G.M.d., Lobo, D.S.: Relationships and Centrality in a Cluster of the Milk Production Network in the State of Parana/Brazil. In: Umeda, S., Nakano, M., Mizuyama, H., Hibino, N., Kiritsis, D., Cieminski, G.v. (eds.) Advances in Production Management Systems: Innovative Production Management Towards Sustainable Growth, pp. 11-19. No. 459, Springer International Publishing (2015)

8. Brazilian Institute of Geography and Statistic: http://www.ibge.gov.br/home/ estatistica/economia/demografiaempresa/2013/default.shtm

9. Unipar: http://www . tvup.org.br

10. Yoon, J., Lee, H.Y., Dinwoodie, J.: Competitiveness of Container Terminal Operating Companies in South Korea and the Indus-try-University-Government Network. Transportation Research Part A: Policy and Practice 80, 1-14 (2015)

11. Papadelis, S., Stavrakas, V., Flamos, A.: What Do Capacity Deployment Rates Tell Us about the Efficiency of Electricity Generation from Renewable Energy Sources Support Measures in Greece? Energies 9(1), 38 (2016)

12. Kulovesi, K.: International Trade Disputes on Renewable Energy: Testing Ground for the Mutual Supportiveness of WTO Law and Climate Change Law. Review of European, Comparative \& International Environmental Law 23(3), 342-353 (2014)

13. Ministry of Development, I., Trade, F.: Tech. rep.

14. Gulati, R.: Alliances and Networks. Strategic management journal pp. 293-317 (1998)

15. Nohria, N.: Is a Network Perspective a Useful Way of Studying Organizations? In Nohria, N.; Ecles, R. Networks and Organizations: Structure, Form, and Action. Harvard Business School pp. 287-301 (1992)

16. Schmitz, H.: Collective Efficiency and Increasing Returns. Cambridge Journal of Economics 23(4), 465-483 (1999)

17. Ministry of Development and Foreign Trade: http://www. desenvolvimento.gov.br

18. Schmitz, H.: Collective Efficiency: Growth Path for Small Scale Industry. The Journal of Development Studies 31(4), 529-566 (1995)

19. Callois, J.M.: The Two Sides of Proximity in Industrial Clusters: The Trade-Off Between Process and Product Innovation. Journal of Urban Economics 63(1), 146-162 (2008)

20. Mintzberg, H., Ahlstrand, B., Lampel, J.: Safári da Estratégia. Bookman (2009)

21. Mulder, L.B., Van Dijk, E., Wilke, H.A., De Cremer, D.: The Effect of Feedback on Support for a Sanctioning System in a Social Dilemma: The Difference between Installing and Maintaining the Sanction. Journal of Economic Psychology 26(3), 443-458 (2005) 
22. Hair Jr, J.F., Babin, B., Money, A.H., Samouel, P.: Fundamentos de Métodos de Pesquisa em Administração. Bookman, Porto Alegre (2005)

23. Creswell, J.W.: Projeto de Pesquisa Métodos Qualitativo, Quantitativo e Misto. Artmed, Porto Alegre (2010)

24. Gil, A.C.: Como Elaborar Projetos de Pesquisa. Atlas, São Paulo (2002)

25. Theóphilo, C.R., Martins, G.d.A.: Metodologia da Investigacao Cientifica para Ciencias Sociais Aplicadas, vol. 2. Atlas, São Paulo (2009) 